How to cite this article:

Ma'dan, M., Imail, M. T., \& Daud, S. (2020). Strategies to enhance graduate employability: Insight from Malaysian public university policy-makers. Malaysian Journal of Learning and Instruction, 17 (2), 137-165. https:// doi.org/10.32890/mjli2020.17.2.5

\title{
STRATEGIES TO ENHANCE GRADUATE EMPLOYABILITY: INSIGHT FROM MALAYSIAN PUBLIC UNIVERSITY POLICY-MAKERS
}

\author{
${ }^{1}$ Marfunizah Ma'dan, ${ }^{2}$ Muhamad Takiyuddin Ismail \& \\ ${ }^{3}$ Sity Daud \\ ${ }^{1}$ School of Government, College of Law, Government \& \\ International Studies \\ Universiti Utara Malaysia, Malaysia \\ ${ }^{2 \& 3}$ Political Sciences Programme, Faculty of Social Sciences \\ and Humanities \\ Universiti Kebangsaan Malaysia, Malaysia \\ ${ }^{I}$ Corresponding author: marfunizah@uum.edu.my
}

Received: 21/8/2019 Revised: 17/5/2020 Accepted: 20/5/2020 Published : 31/7/2020

\section{ABSTRACT}

Purpose - The purpose of this study is to explore the focus and strategies used by public universities in Malaysia, for enhancing their graduates' competency level as well as suggesting ways to reduce unemployment among university graduates. This study aims to identify the focus and strategies of public universities to enhance graduates' competency level, as well as their key challenges.

Methodology - The study used an exploratory research approach by applying a qualitative method. Data were collected through faceto-face interviews with expert informants such as a deputy vice chancellor of academic affairs, directors of graduate employability, and representatives from the alumni centre of eight selected public universities in Malaysia. Data from information provided by informants were analysed using content analysis. 
Findings - The results show detailed explanations and practical roles of Malaysian public universities in enhancing graduates' competency level and subsequently securing their employability by meeting market demands. However, this paper argues for stronger changes and reforms at the institutional level to support the degree of competency among graduates, such as improving teaching methods and programmes offered. Furthermore, university-industry collaboration also needs to be strengthened to develop a competitive and capable talent in the country.

Significance - The paper extends the strategies and focuses that have been implemented by public universities by providing more detailed and practical solutions to ensure that curriculum designs are more effective in supporting the development of graduate competency. Study findings are useful for improving universities' strategies and implementation, to pursue a balanced quality of education in developing future talent.

Keywords: Graduate Employability,University Leaders, Qualitative, Public University, Higher Education Institution, Malaysia.

\section{INTRODUCTION}

\section{Employability of Graduates and Graduate Competency}

The increasing problem of graduate unemployment has been linked to the low level of graduate competency and quality of graduates that does not match with employers' expectations (Aris, Baharum, Sanusi, Abdul-Rahman \& Lee, 2013; Hanapi, Nordin \& Che-Rus, 2014; Perera, Babatunde, Pearson \& Ekundayo, 2017). Velasco (2014) and Nilson (2010) described the difficulty for employers today to find candidates who possess a variety of competencies to facilitate and enhance the organization's productivity. It is therefore vital to address the enhancement of graduates' competency to ensure that graduate employment matches market needs in the future. Hence, the research is motivated to find ways to improve graduate competency that can meet industry demand. As highlighted by Saleh and Rosli (2019) and by Periera, Vilas-Boas and Rebelo (2020), one strategy to enhance graduate employability vis-à-vis industry demand is focusing on work-life competency and the key skills needed for the advancement of the organization. This is a complex 
challenge that demands transformation at the higher education institutional level, taking into consideration the perspectives and momentum of the various interest groups concerned (Anicic \& Divjak, 2020; Sin \& Neace 2016). Cotronei-Baird (2019) also argued that the issue of employability skills development is crucial for national and international higher educational institutions, hence the importance of investigating the challenges facing academic leaders and understanding their actual practices.

Although graduate employability and employment in Malaysia are difficult to track in detail, such figures as are given tend to be very high. According to the Malaysian Graduates Tracer Study (Ministry of Education - Higher Education, 2017), a total of 53,373 graduates from across different Higher Education Institutions (HEIs) were unemployed upon graduation, constituting approximately $3.5 \%$ of the unemployment rate in the country. The largest cohort came from the public universities, where the total was 26,776 compared to private universities $(24,808)$, polytechnics $(1,234)$, community colleges (291), and others (268). This unemployment statistic points to an impasse where a rising number of graduates is produced by HEIs yearly, even while striving to hire qualified and competitive candidates remains a challenge for many employers today. A multitude of factors have been linked to this graduate unemployment, among them mismatch of qualifications to market needs or overqualified graduates (Al Nejam, Chong, Ahmed \& Al-Masri, 2017; Osman, Yusof \& Mohd-Nor, 2010; Tan, Chew \& kalavally, 2017; Vona \& Consoli, 2014), lack of interpersonal and social skills (Dhakal, Cornell \& Burgess, 2018; Hajazi, 2016; Tanius, 2018; Yusof \& Jamaluddin, 2017), lack of career guidance and information (Finch, 2013; Jackson, 2013; Palvin, 2014; Rahmat, Ahmad, Idris \& Zainal, 2012; Ren, 2017; Wickramasinghe \& Perera, 2010; Yusof, Jamaluddin \& Mat-Lazim, 2013), and also economic factors (Tan et al., 2017). As such, the Ministry of Higher Education introduced the National Graduate Employability Blueprint 20122017 (NGEB 2012-2017) to produce competent graduates and fulfil national and international workforce needs with $75 \%$ of graduates being employed in their relevant fields within six months of graduation. There are four primary purposes of this blueprint:

i. To support the role of higher education in building Malaysia's human capital stock. 
ii. To suggest that HEIs provide the local talent with opportunities to live their career dreams.

iii. To enable HEIs to design better curricula embedded with core competencies.

iv. To emphasize the achievement of sustainable employability for HEI graduates.

The blueprint defines employability as a potential to secure, maintain, and expand a job at the workplace. The concept of competency to increase employability also indicates adopting the lifelong learning concept with sets of attributes and skills that match those required by industry. This concept of competence is viewed as an output generated from the human capital development process, where the inputs were acquired through education, training, and experience in educational institutions. While the blueprint sets out a holistic process to address graduate unemployment, these issues continue to plague the nation, penetrating the conscience of every responsible party.

As evidenced by the blueprint in Malaysia, there is growing awareness of the need to shift the role of HEIs to provide graduates with a high level of competency and thereby increase graduate employability. Previous studies also indicated that unemployment can be alleviated with strategic planning undertaken by the HEIs, such as ensuring the field offered is in line with the job market, and transforming the administrative view within the institution (Finch, 2013; Nasir, Adam, Rosli, Abdullah \& Azman, 2017; Palvin, 2014; Rok \& Lebe, 2016). This shift triggers debate internationally on how HEIs can produce employable graduates to feed national prosperity with the emergence of a services-based economy. At issue is not only graduates who are able to create and develop new ideas, but at the same time graduates who can utilize their knowledge to provide better services in the advancement of new technological and global economic areas. Based on the above explanations, the research objectives of this study are:

i. To identify the focus and strategies of public universities to enhance graduates' competency level.

ii. To identify key challenges faced by public universities to enhance graduates' competency level. 
The corresponding research questions are:

i. What are the focus and strategies used by public universities to enhance graduates' competency level?

ii. What kind of key challenges are faced by public universities to enhance graduates' competency level?

\section{The Context of the Study}

This study was conducted at a number of public universities in Malaysia.A public university is a focal point for the young generation, and especially for those completing their education at the secondary school level. Even though many other choices are available to further their studies, public universities have always been one of the first choices for many citizens in Malaysia. Da Wan, Sirat and Razak (2015) propose that, public universities have an advantages in comparing with private universities. The author posit that due to the financial support given by the government, public university is able to focus on nation's social capabilities and social mobility.

Currently, there are 20 public universities in Malaysia which can be categorized into three groups, namely research universities (focusing on research), focus universities (focusing on specific areas related to the formation of the institution), and comprehensive universities (offering a variety of study fields). As an HEI, the university aims to be excellent in all areas including teaching, learning, and research. In this context, HEIs that can meet the aspirations of developing countries in line with the advancement of the economy constitute an important human resource channel. However, based on the statistics provided by the Ministry of Education (Higher Education, 2017), the public universities in Malaysia produced a higher number of unemployed among graduates compared to other HEIs. Therefore, in line with the nation's intention to provide holistic talent for country development, systematic effort at the institutional level needs to be emphasized to ensure that graduate competencies are assessed based on industrial market needs. Chavez, Camello, Dotong and Pamplona (2017) indicated that "most studies in employability have found, knowledge, skills, and attitudes acquired during the period of study at HEIs are among the assets for graduates to gain employment" (p. 155). This clearly shows that the strategies that HEIs employ are vital for graduates not just for their education, but for the cultivation 
of cultural and personality traits for their employment. More broadly, the HEIs' contribution is not only for the enhancement of national economic development, but also to expand the people's thinking, ethics, and economic situation towards a better quality of wellbeing. Thus, the study aims to report the outcome supporting the institutional approach to enhance the graduate's competency level.

\section{Institutional Theory}

Institutional theory explicates the roles of institutions in planning and implementing the government policy for the sake of citizens' interest. In the Political Science context, Schmidt (2015) indicated that institutions embrace various approaches or methods - understood as rules, structures, and more general contexts that influence the outcome of political action and inform political behaviour. Burch (2007) and Egeberg (1999) suggest that public institution can act as agents in linking governmental bodies and citizens. In this case, the government uses the institution as a liaison, so that every introduced policy can be implemented at the institutional level in a smooth and effective manner.

In the context of this study, NGEB 2012-2017 was introduced by the government to alleviate unemployment among Malaysian graduates with the aim to increase employability and produce graduates who are competent to fulfil their goals. Thus, both public and private educational institutions have a crucial responsibility to undertake transformation aimed at producing highly competent graduates to fulfil the market needs. Morphew and Huisman (2002) also explain that an institutional theory can be utilized as a mechanism to understand what changes are being made to improve the quality of education. This statement is also supported by Burch (2007), who states how the policy of education interacts within the same organization to generate positive outcomes. In this case, according to DiMaggio and Powell (1983), there are three things that can create harmony and stability between institutions within the same organizational environment, using the concepts of "coercive", "mimetic", and "normative". In this context, changes made in an institution include all of the organizations involved, namely suppliers (government agencies, legislative bodies), customers (student development, industry), and authorities. As such, Bond, Spronken-Smith and Hussain (2016) found that there are five components that enable 
institutions, in particular HEIs, to restructure and transform quality and enhance competitive graduates: external factors, structures and procedures, development, student achievement, and environmental factors (culture/norms). These five components influence all aspects of an institution and also have the power to influence one another (Bond et al., 2016).

Aligned to this, the role of the institution is important in responding to industry demand for high-quality graduates, not only to enhance the economic development of the country, but also to produce capable talent that will serve the community in various aspects and circumstances. Studies conducted by Yusoff et al. (2008), Maniam and Liong (2007), Husain et al. (2015), Aris, et al. (2013), Palvin (2014), and Buntat, Saud and Hussain (2008) also indicate that the most important thing to support graduates in facing the job market is to provide a suitable programme of study according to the requirements of employers and the industrial market. Thus, the role of educational institutions is crucial in making changes in learning structures and appropriate programmes to ensure that HEIs are successful in producing highly skilled graduates by providing appropriate quality of education in line with current industry and market demands.

\section{METHODOLOGY}

\section{Research Approach}

Guided by the two research objectives, this study used an exploratory research approach. This approach is suitable for this study to identify the problems, then make a justification based on the situation or practice at the institutional level. Eight public universities were selected to represent the 20 public universities in Malaysia, including two from the research university category three from the focus university category and the other three from the comprehensive university category. These eight universities were selected based on the percentage of employment among graduates from public universities in 2017. As well, universities from these three categories were selected to explore the focus and strategies used by them in enhancing their graduates' competency level particularly based on their structure, norms, development, and student achievements. Their challenges in achieving their mission to alleviate unemployment and 
enhance graduates' competency level were also emphasized in this study. The percentages of graduate employability from the selected universities are shown in Table 1.

As listed in Table 1, eight public universities were selected for the data collection process for this study. Selection of these universities was based on the highest and lowest percentage of graduate employability according to the Higher Education Statistics in 2017, from the three categories. A further aspect was also considered: the 2016 percentage of graduate employability was 50.9 percent, indicating a drop of about 0.6 percent in 2017, while graduate employability for Universiti Malaysia Sabah was at 46.4 percent, indicating a drop of about 10.2 percent in 2017. Therefore, these two universities were included in this study to identify the key challenges that they faced to sustain the employability of their graduates.

Table 1

Graduate Employability Percentage for Eight Selected Universities

\begin{tabular}{|c|c|c|c|}
\hline No. & University & $\begin{array}{l}\text { University } \\
\text { Category }\end{array}$ & $\begin{array}{c}\text { Graduate } \\
\text { Employability } \\
\text { Percentage of } \\
2017\end{array}$ \\
\hline 1. & Universiti Sains Malaya (USM) & $\begin{array}{l}\text { Research } \\
\text { University }\end{array}$ & $64.1 \%$ \\
\hline 2. & Universiti Putra Malaysia (UPM) & $\begin{array}{l}\text { Research } \\
\text { University }\end{array}$ & $56.3 \%$ \\
\hline 3. & $\begin{array}{l}\text { Universiti Malaysia Pahang } \\
\text { (UMP) }\end{array}$ & $\begin{array}{l}\text { Focus } \\
\text { University }\end{array}$ & $77.4 \%$ \\
\hline 4 & $\begin{array}{l}\text { University Malaysia Terengganu } \\
\text { (UMT) }\end{array}$ & $\begin{array}{l}\text { Focus } \\
\text { University }\end{array}$ & $50.3 \%$ \\
\hline 5. & $\begin{array}{l}\text { Universiti Sultan Zainal Abidin } \\
\text { (UniSZA) }\end{array}$ & $\begin{array}{l}\text { Focus } \\
\text { University }\end{array}$ & $34.7 \%$ \\
\hline 6. & $\begin{array}{l}\text { International Islamic University } \\
\text { of Malaysia (IIUM) }\end{array}$ & $\begin{array}{l}\text { Comprehensive } \\
\text { University }\end{array}$ & $50.5 \%$ \\
\hline 7. & $\begin{array}{l}\text { Universiti Malaysia Sarawak } \\
\text { (UNIMAS) }\end{array}$ & $\begin{array}{l}\text { Comprehensive } \\
\text { University }\end{array}$ & $46.3 \%$ \\
\hline 8. & Universiti Malaysia Sabah (UMS) & $\begin{array}{l}\text { Comprehensive } \\
\text { University }\end{array}$ & $36.2 \%$ \\
\hline
\end{tabular}

Source: Higher Education Department, Ministry of Education 2017 


\section{Data Collection Procedure and Technique}

Data collection procedure for this study was based on the qualitative method with the aim to explore the real phenomenon of the study context. Past research propose that qualitative methods are unique in term of obtaining a richer information because they may provide a further validation and confirmation of the data (Parker, 2003 \& Wahyuni 2013). Therefore, the best way to verify the situation is through face-to-face communication with the individuals involved. Thus, researchers choose to conduct a face-to-face interview with appropriately identified informants as germane to the objectives of the study. As mentioned by Yusof et al. (2019), the credibility of the data can be verified by collecting data from expert informants who are directly involved in the situation under study. Moreover, they can share not just their knowledge, but the experience on the phenomenon of the study. This is important to enhance the rigor and trustworthiness of the study. In the context of this study, face-to-face interviews were conducted among eight informants representing the selected public universities as listed in Table 1. They comprised a Deputy Vice Chancellor for Academic Affairs as well as Directors of Graduate Employability and Alumni Centre for the eight selected universities, and were labelled as DV1 for Deputy Vice Chancellor and DG for Director of Graduates.

In this study, the interview questionnaire was constructed based on semi-structured questions, whereby the interview questions were developed according to a theme and objective without deviating to other topics. The three themes were based on the objectives of the study namely (1) focus, (2) strategy, and (3) challenge of the university in enhancing graduate's competency level. Most of the interviews were conducted at the office of the respondent and were tape-recorded with their permission. Each interview was transcribed and read by the researchers several times to ensure the accuracy of the data. Even though the interview session used Malay language and sometimes the informant give the answer in Malay and English, the data were fully translated into English and reviewed by expert proof-readers.

After that, the analysis process for the data collected was based on the content and information given by all informants selected. Figure 2 describes the data analysis process of the study. 




Figure 2. Data Analysis Process.

Figure 2 above shows the process of analysing data for the qualitative method used by the researcher. First is the process of shaping the theme, where the focus is on the pattern given by the informant through the interview process. Designing such themes will help researchers to differentiate the data obtained to facilitate the appropriate combination of data. Next is the data encoding process which involves three stages: open coding, axis coding, and selected coding. First, the data were coding based on predefined themes and categories. After that, individual pieces of data were collected based on the content and included in categories. Finally, the selective coding process established logical relationships among the data to gain understanding of the phenomenon of study. The final process in qualitative analysis is forming an interim conclusion, which is an interpreted conclusion of the findings according to the objectives of the study.

\section{RESULTS AND DISCUSSION}

Four main themes emerged from the interview analysis: 1) focus on enhancing graduates attribute, 2) strategies and challenges in enhancing graduates attribute, 3) focus on collaborating with industry, and 4) strategies and challenges in collaborating with industry. All of this analysis is summarized in Table 2 . 
Table 2

Main Themes of Interview Analysis

\begin{tabular}{|c|c|c|}
\hline Focus & Strategies & Challenges \\
\hline $\begin{array}{l}\text { Nurture Graduate } \\
\text { Attribute } \\
\text { 1) Teaching and } \\
\text { Learning } \\
\text { Development } \\
\text { Programme }\end{array}$ & $\begin{array}{l}\text { Review irrelevant } \\
\text { courses } \\
\text { Strengthen the } \\
\text { curriculum for } \\
\text { teaching and } \\
\text { learning programs } \\
\text { - Create value- } \\
\text { added programmes } \\
\text { through student } \\
\text { affairs department }\end{array}$ & $\begin{array}{l}\text { Strain at the } \\
\text { university level } \\
\text { vis-à-vis change }\end{array}$ \\
\hline $\begin{array}{l}\text { 2) Teaching and } \\
\text { Learning } \\
\text { Implementation } \\
\text { Programme }\end{array}$ & $\begin{array}{l}\text { Improve the skills } \\
\text { and capabilities } \\
\text { of lecturers at the } \\
\text { university } \\
\text { - Implemented most } \\
\text { effective teaching } \\
\text { techniques such } \\
\text { as outcome-based } \\
\text { learning, student- } \\
\text { centred learning, } \\
\text { active learning, and } \\
\text { others }\end{array}$ & $\begin{array}{l}\text { There is a minority } \\
\text { of lecturers who are } \\
\text { lacking in terms of } \\
\text { knowledge and skills } \\
\text { to carry out more } \\
\text { effective teaching } \\
\text { methods according to } \\
\text { the current situation } \\
\text { Most lecturers are } \\
\text { very dependent on } \\
\text { their old norms, } \\
\text { very theoretical in } \\
\text { teaching method }\end{array}$ \\
\hline
\end{tabular}

Collaboration with

Industry

1) Collaboration

in Designing

Teaching

and Learning

Content

2) Collaboration

in Graduate

Development

Programmes

- Involve industry

to handle students'

activities and

programmes:

exposure

programme on the

course taken, etc. 
Focus

Strategies

Challenges

3) Collaboration in Teaching and Learning Implementation
- Offered industrial training

- Provided training to lecturers and staff
- Lack of monitoring of departments and companies chosen by students

\section{Focus: Enhancing Graduate Attribute}

In a knowledge-based economy, degrees are not only important for employment. However, Kutty and Azman (2016) explained that, "they can also be crucial for the young generation, especially from the middle class and below, as their capital to secure financial development" (p.140). Thus, the role of HEIs - and especially public universities which are the subject of this study - is vital to nurture and secure graduate employability attributes. Furthermore, the university is no longer just the focus of society as a place to acquire knowledge, as development and economic improvement come about through technological change, talent development, and skilled workers (Da Wan \& Sirat, 2018).

According to Bond et al. (2016), there are several elements to consider in the transformation process undertaken by HEIs, through the application of institutional theory in enhancing the competency level among graduates: structure, norms, development, and student achievement. These criteria are similar to the opinion given by the informants for this study. For example:

We have about five things to look at. Firstly, the student itself. Second, the universities. And in the university, there are three things. Infrastructure, lecturer, and syllabus. Third, the other skills that can be taught. The fourth mechanism is for getting work. When appropriate and in line with the industry or not, it matters. And the last one is the feedback and results that come from different angles. It can come from the students themselves and from the university. (DG1)

This result indicated that the development process at the institutional level includes the structure, norms, programme development, and 
student achievement that will affect all parties at the institutional level (lecturers, students, university), as well enhancing the competitiveness of the university. Therefore, the important aspect at the university level is to sharpen the talent in nurturing the attributes of graduate employability through institutional reforms, including teaching and learning programmes, development programmes for students and faculty, as well as suitable facilities for effective implementation of programmes at the university level. In fact, Kechot and Abdullah (2006) and Hajazi (2016) stressed that reforms at the HEI level are significant for national development, specifically to improve the quality of education in terms of the relevance of programmes offered, a more dynamic environment, and more effective organization/institution management.

\section{Strategies and Challenges: Enhancing Graduate Attribute}

\section{Teaching and Learning Development Programme}

The first HEI strategy to inculcate employability among students is through programme development which includes curriculum and co-curricular activities. Accordingly, based on content analysis from informants representing public universities in Malaysia, it was agreed that both curriculum and co-curricular activities are essential to increase the level of competency among graduates. In fact, Yusof and Jamaluddin (2017) emphasize that "the curriculum of study is one of the important factors that influences the pathway for future students in the market" (p. 21). In addition, training and education in cultivating the moral values of students through cocurricular activities is also important. Although the role of education is generally to educate the public, especially for public universities that are more focused on knowledge than private universities that are more focused on commercial values, the ability of graduates to optimize themselves after graduating from HEIs should be expanded. The role of universities is getting more challenging because they need to produce knowledgeable and skilled generation who needs to be matched with market value or demand (Hajazi, 2016).

The results of the interviews showed that the universities are developing competent graduates with ability and understanding in a field of knowledge, without only relying on academic activities. However, certain skills that relate to the current situation in the new market of industry should be highlighted to give graduates additional 
knowledge in preparation for the real work world. As stated by Chua, Chuatoco, Pena, Jimenez and Co (2017), "fierce competition among current graduates emphasizes the need for them to be on different levels of competency and more prominent than others, especially in a real workplace" (p. 164). In this regard, the first step to be taken by the university is to identify the key courses addressed by the current workplace market. For example, a university informant stated that:

In this case, we need to review irrelevant courses, because if our students take the subject then when they finished their study it may not be offered. We need to look at the market demand for the job first. So, it is worth looking at the university level for the courses that are irrelevant or can be improved. (DG2)

Based on the results obtained, most universities are aware of the need to review irrelevant courses in line with market demand. Similarly, a previous study has also indicated that one of the factors contributing to the increasing percentage of unemployment among graduates is the courses offered that are not in line with current market demand (Hajazi, 2016). Despite this awareness, there is a difference between the real demand for job skills requirements versus what is supplied by education and does not match the employers' requests. This has led to a phenomenon of inequality of education, and there are also graduates who have qualifications beyond the scope of work offered (Al Nejam et al., 2017, p. 87; Osman et al., 2010; Tan et al., 2017; Vona \& Consoli, 2014, p. 8). These criteria are assessed by employers during the hiring process. However, there also some challenges faced within the university itself when it seeks to improve the courses and programmes offered to the student. Accordingly, an informant explained that "sometimes, there are also egos coming from the departmental level. When there is a need for merging, they were not approved and still maintain the current programme" (DG6).

The findings suggest that there has been a growing awareness among university staff members that some courses and programmes need to be transformed and follow the latest market trends to address the problem of unemployed graduates. However, the reality is that not all of these suggestions are well accepted at some of the university's own levels. This situation illustrates that strain within the university itself is also one of the sources contributing towards unemployment 
in the country. Hence, reforms in educational institutions require the support of all parties, including the implementers and the university administrators, to ensure that the learning and instruction provided by the university are relevant to the current economic demand. Thus, the quality of education needs to be emphasized, especially within the public universities, given that many employers and local communities expect public universities to be the primary choice for their children to pursue higher education.

Additionally, the university also agrees to enable graduates to get employment opportunities not just by excellence in the academic field. Other skills such as creative thinking, good communication skills, and being able to self-regulate in any situation are deserving of concern. Studies (Dhakal et al., 2018; Hajazi, 2016, p. 18; Tanius, 2018; Yusof \& Jamaluddin, 2017) point to graduates who are not selected by employers because of their incapability to communicate well, inability to work in groups, lack of creative and critical thinking, inability to make decisions, lack of interpersonal skills, and lack of ability to solve problems. Regrettably, these skills are the key features of marketability as seen from the employer's perspective. Hence, at the university level, various activities are being organized especially through the student affairs department to increase the level of competency among graduates and to ensure that they have good preparation to cope with the job market. For example, one informant (DG4) stated that "we will always create value-added programmes for these students through various skills to be interviewed, for level of confidence, leadership, and so on".

Thus, curriculum development and student co-curriculum programmes are complementary and need to be improved periodically. In this case, the university itself must strengthen the curriculum for teaching and learning programmes in line with current demands - without disregarding knowledge in a field that students should learn. As such, the study indicated that some reforms in terms of teaching and learning, particularly employment-oriented teaching, can be applied through programmes and courses offered at HEIs. Such reforms not only can benefit individuals by deepening students' understanding of their future career, but also can balance the supply and demand of market needs (Sun, 2019). Besides that, improvements in professional curriculum also can benefit today's students. For example, offering a major course with multiple choices of minor course can enhance the capabilities of students as well as 
increase their level of self-competitiveness. Therefore, the balance of quality education in teaching and learning programmes should be reviewed periodically to provide for student employment in the future. At the same time, the spiritual aspect of the student should not be underestimated. This is because these additional activities will reinforce the identity of the student. Not only that, the support from the university itself to provide a balanced quality education in a variety of aspects is desirable to create a balanced, harmonious, and unique talent for better survival in the future.

\section{Teaching and Learning Implementation Programme}

Improved achievement among students will not be successful without training of the existing lecturers. More importantly, the quality and excellence of a student are dependent on the teaching and learning methods delivered by their lecturers (Lee et al., 2018). Although the delivery method used by lecturers is one of the important influences to improve the quality of students, there are still a minority of lecturers who are lacking in terms of knowledge and skills to carry out more effective teaching methods as appropriate to the current situation. For this reason, the university also implements programmes to improve the skills and capabilities of its lecturers. As such, one informant (DG3) explained:

Training is given to lecturers on how to improve the skills related to teaching and learning programme. For example, we need communication skills, how to improve confidence in delivery, and so on. Therefore, they need training or course work related to the skills.

Thus, the culture or norms among lecturers concerning teaching and learning in the classroom greatly influences the level of competency among graduates. Additionally, researchers have found (Yusof \& Jamaluddin, 2017; Yusof \& Norain, 2013) that one of the reasons why the quality of public university graduates is less than that of private universities is due to the teaching method in public universities, which is more traditional and overly theoretical. At the same time, the university acknowledges that there are some constraints to implementing a new teaching and learning programme. For example, an informant (DG6) stated that "most lecturers are very dependent on their old norms. Very theoretical..." 
Based on the above statement, cultural factors among lecturers play a significant role in influencing the quality of student education. This is supported by Bond et al. (2016) who state that the environmental factors that embody the culture, norms, and institutional fortunes also influence every action and outcome of the institution. In fact, Nasir et al. (2017) and Rok and Lebe (2016) found that the quality of education in an institution depends on the quality of teaching and learning applied. Therefore, to improve the quality of services and outcomes in educational institutions, changes in culture, norms, and attitudes are needed. In this regard, most public universities today have adopted more innovative and open teaching methods than ever before. This is evident when the university states that some of the most effective teaching techniques have been implemented, such as outcome-based learning, student-centred learning, active learning, and others. Moreover, Omar (2016) conceded that "conventional and theory-based lectures are simply less effective for students in this era" (p.16). Also, today's society is no longer lagging behind technology, but is highly sophisticated in its use of such technologies. At the same time, traditional lecture-based delivery techniques cannot be simply ignored, as they are still needed to convey important elements in education.

The university lecturers of today need therefore to apply a more active, creative, and innovative teaching and learning culture as well as to motivate students to be more competitive. As predicted in the Malaysian Education Blueprint (2015-2025) (Higher Education, 2013), to improve the performance of high calibre, competent, and market-oriented graduates, HEIs should emphasize not only improvements in the teaching curriculum, but also a more effective delivery system and according to the current needs of students. Additionally, effective teaching methods not only help students to understand the lessons in the classroom, they also help teachers to deliver their instruction better.

\section{Focus: Collaborating with Industry}

Industrial cooperation is one of the important factors in developing more competitive human capital. Perspectives provided by industry contribute to the idea of increasing the level of competency of graduates, while at the same time trying to reduce the unemployment rate in the country. According to Anas and Hamzah (2017), Minocha et al. (2017,p.9), and Tanius (2018), the involvement of industry both 
directly and indirectly - whether brainstorming ideas or providing advice to educational institutions about the skills, knowledge, and features of employability required in the current market - is necessary for updating the curriculum. In line with this, Henrich (2016) argues that the cooperation between educational institutions and employers are pertinent for graduate employability. In particular, the cooperation is about the consolidation of the required graduate competency level as desired by the industry/employer that are accessible and provided by the educational programme offerings.

Furthermore, the key factors that lead to the employment rate in Malaysia are not only focused on universities and students, as industry has aligned interests and contributes periodically to the level of HEI graduates, through facilitating the development of teaching and learning programmes in universities in order to increase the level of competency of graduates and of university lecturers. In this context, the university believes that reduction of the unemployment rate involves not just one party. In fact, the cooperation between the two parties, namely universities and industry, is necessary to eradicate this problem. According to a study informant (DG3):

In this case, it does not just involve one party. It's interrelated. When industry want to expand their business, why not hire our fresh graduates. I believed their competency will be increased when given the opportunity to learn more deeply about one field.

The results show that the responsibility to reduce the unemployment rate in the country lies not just in the hands of the university. At the same time, industry should work together to provide job opportunities for new graduates who are still inexperienced. Even when the unemployment problem is unpredictable, it can still be reduced by the cooperation of various stakeholders, especially the university and its industry partners.

\section{Strategies and Challenges: Collaborating with Industry}

\section{Collaboration in Designing Teaching and Learning Content}

A collaboration between universities and industry is essential mainly in the fundamentals of teaching and learning, including in the form of teaching content. This is acutely important as it is one of the 
issues that contributes to the inequality of graduates today, where the courses are not in line with the needs of employers as well as the current market. According to Laguador and Ramos Jr. (2014), the cooperation of university and industry in designing the curriculum for certain programmes helps avoid inaccuracies and allows courses to be tailored according to the competency of graduates required by the employer. More importantly, key inputs from industry in the development of the curriculum programme can prevent industry uncertainty about the eligibility of university graduates. This is in line with the work of Aida and colleagues (2015), who found that matching criteria based on employer demand is one of the success factors to increase the rate of graduates' employability in the country. Therefore, the university believes in offering new courses in line with the requirements of the job market as well as what employers are looking for, which generally requires input from both parties. Unfortunately, although certain university knows the importance of industry to provide input in the development of programmes in line with current needs, the success of this collaboration is still disputed when the problem of unemployed graduates remains high. In this case, an informant stated that:

Input from industry is important. Because the industry will receive products from the university. So generally, the university knows to reform the programme according to the needs of the industry. But this does not really happen, and if it happens, just only for a certain faculty. (DG6)

Hence, this informant's statement gives rise to uncertainty about how much input from industry can be absorbed into the reforms made at the university level. Nonetheless, "cooperation between university and industry is important in terms of innovation, aimed at increasing and strengthening research and resources in the context of new knowledge, ideas, intellectuality, and more effective management" (Draghici, Baban, Gocan \& Ivascu, 2015, p. 25). Additionally, the need for new sources and research is very important for the country to provide products and services in line with today's increasingly competitive economy.

\section{Collaboration in Graduates Development Programme}

In the process of designing the teaching and learning content, university-industry collaboration in planning programme 
development has become of interest in efforts to improve the level of competency of graduates. To this end, various activities have been planned and conducted at the university level as a strategy to improve the quality of teaching and learning at the university. As such, one informant (DG2) explained:

\begin{abstract}
Besides linking with industry, like industry talk continues to be on campus, we require industry to come and meet with students for certain subjects. Sometimes our universities do not understand what the industry needs and wants. So, we invite industry to meet with students and tell us what they want from students. So, we engage with some companies.
\end{abstract}

In this regard, St. Jorre and Oliver (2017) have also found that when students self-listen and experience exposure from the employers' perspectives, they will become more motivated and committed to their field of study in HEIs. Therefore, researchers such as Finch (2013), Jackson (2013), Palvin (2014), Rahmat, Ahmad, Idris and Zainal (2012), Ren (2017), Wickramasinghe and Perera (2010), and Yusof et al. (2013) contend that graduates should be given the latest information on job opportunities and markets by the HEIs, according to the field of study. Collaboration between the university and industry will thereby incentivize students towards programmes of study that are relevant to the latest market needs.

Collaboration with industry to ensure that necessary courses of study are in line with the local market also highlights the advisability of the university advocating career-related activities as a preparation for students before facing the working world, such as finishing school, booth camp, career fairs, and so on. Exposure programmes like this are important for graduates to gain awareness and knowledge, as well as improve their skills according to current market needs and requirements. More importantly, functionality in industry is constantly changing according to current economic conditions, which results in job cuts in certain sectors. Hence, this will lead to the emergence of new job fields that require a different set of individual competencies to work more efficiently and effectively. A university that stays comfortable with the existing conditions, and does not take the opportunity to collaborate with industry in developing the latest learning programmes, will soon lag behind. As a result, its graduates will not be prepared to enter the proper field of work in the future. 


\section{Collaboration in Teaching and Learning Implementation}

Continuous education and training are essential to building a student's abilities. In addition to providing knowledge in the classroom, training on the area's needs should be emphasized for the convenience of graduates when entering their field of work. At the university level itself, industrial training is offered as one of the conditions for obtaining a degree. As such, one informant gives the statement that:

We have practical courses in universities where we call it industrial training. This is a compulsory requirement. If for the diploma programme, it has about six months of industrial training programme. Three months to six months is sufficient for students to gain knowledge in the industry. (DG3)

Industrial training is one of the measuring sticks in a career-based learning approach (work-based learning). By implementing industry training as one of the courses offered, universities can enable students to get exposure and gain experience, to engage in jobs relevant to their field of study. In addition to acquiring experience, students also can improve their skills, especially from the perspective of technical and interpersonal skills. Findings reviewed by St Jorre and Oliver (2017) stated that industry cooperation through programmes at universities, such as industrial training, is one of the effective ways to build employability skills amongst students. At the same time, the university should always monitor the criteria of those departments or companies that are chosen by the students. This is to ensure the quality of student experience from industrial training, which is very crucial to their personal development and career success in the future.

In addition to providing industrial training as one of the courses for students, the university should also provide training to the lecturers, to ensure that the teaching and learning delivered are in line with industry needs. Lecturers should master both the theoretical and practical skills to facilitate their teaching and learning activities in the classroom (Sukadi et al., 2015), as the skills of each lecturer will impact the understanding of each student, to apply in their actual work in future. For example, the informant (DG3) explained that "in terms of teaching staff, each faculty will send a staff member to go for attachment at relevant industry to get some required competency". 
It can be concluded that the collaboration of lecturers to practice teaching and learning at universities, in line with current employment/ industry needs, should be strengthened. This is important not only to enhance their knowledge, but also to develop competitive talent in the future. In this context, collaboration between universities and industry is important not just to develop relevant skills for the students, but also to implement opportunities for the lecturers, especially those who use technical skills in teaching and learning processes. Most importantly, the technologies are changing very fast. If the university does not act quickly to provide relevant courses to its lecturers, a balanced and high quality education cannot be achieved by students. As a result, they will be left behind in terms of the technology needed in the current industry. When lecturers are given the opportunity to obtain skills directly from industry, it will create perceptions among employers that the quality of the programme of study at universities is now equivalent to what they want. In addition, this can improve the job-readiness of graduates.

\section{CONCLUSION AND RECOMMENDATIONS}

This study explores the focus and strategies used by public universities in Malaysia to enhance graduates' competency level as well as to alleviate the unemployment issues among current graduates. The study found that public universities are focusing on nurturing their graduates' attributes and collaborating with industry to enhance the graduates' competency level. All strategies used, involving structure, norms, development, and student achievement programmes at the university level, are certainly affecting the overall aspects of the student, the teaching staff, and the university as a whole. As presented in Table 2 above, the universities are focusing on teaching and learning development including teaching and learning method, restructuring programme offerings, and increasing students' curriculum and added-value activities to enhance the graduates' competency level. In addition, external factors such as accreditation bodies, collaboration between stakeholders such as industry, technology, and others affect all aspects of the reforms undertaken by the university. Thus, each of these reforms is in line with the institutional theory proposed by Bond et al. (2016), which involves structure, development, student achievement, culture, and external factors. In this regard, each of these aspects should be periodically engaged by the university to improve the quality of 
education. This also coincides with Morphew and Huisman's (2002) statement that institutional theory is the mechanism to understand what strategies can be taken to improve the quality of education. Thus, this study expands the understanding of the institutional theory as the mechanism to improve the quality of the education particularly in Malaysia. This support the institutional approach in terms of the governance and managerial system in the institutions. However, there are some challenges faced by the university in the transformation process. Although some initiatives have been taken and there is awareness among university staff concerning the need to make changes in the administration of the university, the efforts have not yet been fully realized. Certain constraints may exist involving changes in the administrative structure of some programmes and departments, such as disagreements between certain parties within the department. Thus, the situation remains that there are still graduates who are forced to accept any job offer that arises, even though it is not in line with their area of study. Be that as it may, the university is a complex institution for the development of all levels of society, and should be able to provide a comprehensive education covering many aspects. Thus, the educational system in the context of institutions and governance needs to be strengthened from time to time. This includes providing balanced education through the transformation process in educational institutions, providing knowledge to reinforce the way of thinking that can help improve prospects economically and individually, with the natural sense of responsibility to contribute to society.

In addition, cooperation between educational institutions and industry is critically necessary for the development of teaching and learning. Although there are universities that involve industry in designing the curriculum and co-curriculum of teaching and learning, the extent to which such inputs are well received by the university is still uncertain and the success of such efforts is disputed. Therefore, university-industry collaboration needs to be strengthened as it will have a positive impact on output for research development, economic growth, and the enrichment of both institutional and industrial capabilities for the development of the country. More importantly, cooperation between universities and industry will increase the country's new talent from a more dynamic and competitive human capital development perspective. Although the primary role of the university is to give knowledge based on the theoretical aspect, investment in higher education should not be 
neglected by society. Moreover, achieving enhanced state status in the future means building capacity and having a highly innovative society. On the other hand, the role of industry is also important, not just by giving the right signal concerning current needs, but also providing real-time opportunities for students and faculty. In this regard, the cooperation of both parties is crucial to create a "winwin" situation for all involved as well as to develop a holistic talent in the future.

This study has some limitations. First, the sample size was confined to eight informants from the selected public universities as respondents for this study. A much larger sample size is recommended to ensure and gather a wide range of information to expose this issue. Apart from that, further studies at different types of public and private universities are recommended to enable the development of a comprehensive approach to enhance graduates' competencies. Thus, the findings can be increased through comparative systematic analysis based on these two institutions, specifically to alleviate unemployment issues in this country.

\section{ACKNOWLEDGEMENTS}

The authors of this study would like to thank all the informants who represent eight selected public universities in Malaysia for their commitment and time to participate in the interview session. This study has not received any specific grant from any agency.

\section{REFERENCES}

Aida, B., Norailis, A. W., \& Rozaini, R. (2015). Critical success factor of graduate employability programs. Journal of Economics, Business and Management, 3(8), 767-771.

Al Nejam, A., Chong, A. T. C., Ahmed, M. S., \& Al-Masri, O. (2017). A conceptual framework for mitigating graduate employment problems. Journal of ICT in Education, 4, 81-87.

Anas, I., \& Hamzah, S. R. (2017). Conceptual study on the enhancement of employability among undergraduates in workbased learning setting. International Journal of Academic Research in Business and Social Sciences, 7(4), 65-79. 
Anicic, K., P., \& Divjak, B. (2020). Maturity Model for supporting graduates' early careers within Higher Education institutions. SAGE Open, 1-14. DOI: 10.1177/2158244019898733https:// doi.org/10.1177/21582440198987

Aris, N. A., Baharum, Z., Sanusi, Z. M., Abdul-Rahman, I. K., \& Lee, T. H. (2013). Assessment of critical success factors for accounting graduates employability. IEEE Business Engineering and Industrial Applications Colloquium, 526531.

Bond, C. H., Spronken-Smith, R., McLean, A., Smith, N., Frielick. S., Jenkins, M., \& Marshall, S. (2016). A framework of enabling graduate outcomes in undergraduate programme. Higher Education Research \& Development, https://doi: 10.1080/07294360.2016.1170767.

Buntat, Y., Saud, M. S., \& Hussain, H. A. (2008). Cabaran Politeknik Sultan Ahmad Shah (POLISAS) membangunkan modal insan sejajar dengan keperluan sektor industri. In 3rd International Conference on Education, 1-12.

Burch,P.(2007). Educational policy and practice from the perspective of institutional theory: Crafting a wider lens. Educational Researcher, 36(2), 84-95.

Chavez, N. H. Camello, N. C., Dotong, C. I. \& Pamplona, M. A. I. 2017. Employability of Engineering graduates from 20132015 as basis for a proposed student development program. Asia Pacific Journal of Multidisiplinary Research, 5(1), 155166.

Chua, C. J. E., Chuatoco, I. A. G., Pena, A. M. C. D., Jimenez, D. L. F., \& Co, D. A. (2017). The influence of participation in extracurricular activities to the employability of industrial Engineering graduates of one private university in Philippines. Asia Pacific Journal of Multidisciplinary Research, 5(2), 163 170.

Cotronei-Baird, V., S. (2019). Academic hindrances in the integration of employability skills development in teaching and assessment practice. Higher Education. https:// doi.org/10.1007/s10734019-00405-4

Da Wan, C., \& Sirat, M. (2018). The Development of Malaysia Higher Education: Making sense of the nation-building agenda in the globalisation area. Asian Education and Development Studies. https://doi.org/10.1108/AEDS-07-2017-0068

Da Wan,C., Sirat, M., \& Razak, D.A. (2015). The idea of a Universiti: Rethinking of Malaysia context. Humanities, 4, 266-282. 
Dhakal, S. P., Connell, J., \& Burgess, J. (2018). Inclusion and work: Addressing the global challenges for youth employment, equality, diversity and inclusion: An International Journal, 37(2), 110-120.

Draghici, A., Baban, C., Gogan, M., \& Ivascu, L. (2015). A knowledge management approach for the university-industry collaboration in open innovation. Procedia Academic and Finance, 2, 23-32.

Egeberg, M. (1999). The impact of bureaucratic structure on policy making. Public Administration, 77, 155-170.

Finch, D. J., Hamilton, L. K., Baldwin, R., \& Zehner, M. (2013). An exploratory study of factors affecting undergraduate employability. Education \& Training, 55(7), 681 - 704.

Hajazi, M. Z. (2016). Strategi menghasilkan generasi cemerlang melalui pendidikan: Peranan Universiti. Proceeding, International Seminar of Education 2016. Faculty of Tarbiyah and Teacher Training. 15-22.

Hanapi, Z., Nordin, M. S., \& Che-Rus, R. (2014). Unemployment problem among graduates of technical field: Competencies of the graduates and quality of the education. Sains Humanika, 2(2), 53-57.

Henrich, J. (2016). Competency-based education: The employer's perspective of Higher Education. Competency-based Education, 1, 122-129. https://doi: 0.1002/cbe2.1023

Husain, M. Y., Mokhtar, S. B., \& Alias, A. H. (2015). Persepsi pelajar kejuruteraan politeknik terhadap kemahiran employability: Satu kajian kes (Polytechnic Engineering students perceptions of the employability skills: A case study). Advanced Journal of Technical and Vocational Education, 1(2), 25-32.

Jackson, D. (2013). Student perceptions of the importance of employability skill provision in Business undergraduate programs. Journal of Education for Business, 88, 271-279.

Kechot, M. Z., \& Abdullah, I. H. (2006). Amalan pengurusan dan budaya kualiti institusi pengajian tinggi di Malaysia. Pusat Pembangunan Akademik Universiti Kebangsaan Malaysia: Bangi.

Ken, T. T. S., \& Ying, C. Y. (2012). Business graduates' competencies in the eyes of employers: An exploratory study in Malaysia. World Review of Business Research, 2(2), 176-190.

Kutty, F. M., \& Azman, N. (2016). Mapping the journey of firstgeneration students: Their goals and transition to University. in Abdullah, M. N. L. Y. \& Md. Zain, A. N. Towards Sustainable 
and Inclusive Higher Education: Challenges and Strategies. (pp. 140 - 145). Universiti Sains Malaysia: Pulau Pinang.

Laguador, J. M., \& Ramos Jr., L. R. (2014). Industry-Partners' preferences for graduates: Input on curriculum development. Research Academy of Social Sciences, 1(1), 1-8.

Lee, H. L., Che-Abas, A. I., \& Shaari, J. (2018). The influence of active teaching-learning methods on student's academics performance in Mandarin courses: Undergraduates in focus. International Journal of Language Education and Applied Linguistics, 8(2), 51-60.

Maniam, U. M., \& Liong, C. Y. (2007). Persepsi pelajar terhadap atribut pekerjaan dan implikasinya ke atas pendidikan Universiti. Sains Malaysia, 36(2), 213-223.

Ministry of Education Malaysia. (2012). The National Graduate Employability Blueprint 2012-2017. Putrajaya: Perpustakaan Negara Malaysia.

Ministry of Education Malaysia (Higher Education) (2018). Graduate Tracer Study Report 2017.

Minocha, S., Hristov, D., \& Reynolds, M. (2017). From graduate employability to employment: Policy and practice in UK Higher Education. International Journal of Training and Development, https://doi: 10.1111/ijtd.12105.

Morphew, C. C., \& Huisman, J. (2002). Using institutional theory to reframe research on academic drift. Higher Education in Europe, 27(4), 491-506.

Nasir, N., Adam, S. B., Rosli, N. N., Abdullah, M. S., \& Azman, M. N. A. (2017). Kompetensi pembimbing dalam sistem latihan kemahiran dua hala: Satu sorotan literatur. Sains Humanika, 9, 1-5.

Nilsson, S. (2010). Enhancing individual employability: The perspective of engineering graduates. Education \& Training, 52(6/7) 540-551.

Omar,W. (2016). Kelestarian Pendidikan Tinggi ke arah penghasilan berimpak. Penerbit UTM Press: Universiti Teknologi Malaysia, Johor.

Osman,Z., Yusoff,I., \& Mohd-Nor,A.H. S. (2010).Inflasi pendidikan mengikut ketentuan dalam pasaran buruh Malaysia. Jurnal Ekonomi Malaysia, 44, 61-71.

Palvin, S. (2014). The role of higher education in supporting graduates' early labour market careers. International Journal of Manpower, 35(4),576 - 590. 
Parker, L. D. (2003). Qualitative research in accounting and management: The emerging agenda. Journal of Accounting and Finance, 2, 15-30.

Pereira, E., T., Vilas-Boas, M., \& Rebelo, C., F. (2020). University curricula and employability: The stakeholders' views for a future agenda. Industry \& Higher Education, 1-9. https:// doi. org/10.1177/0950422220901676

Perera, S., Babatunde, S. O., Pearson, J., \& Ekundayo, D. (2017). Professional competency based analysis of continuing tensions between education and training in higher education. Higher Education, Skills and Work-based Learning, 7(1), 1-20.

Rahmat, M., Ahmad, K., Idris, S. \& Zainal, N. F. A. (2012). Relationship between employability and graduates' skill. Procedia - Social and Behavioral Sciences, 59, 591-597.

Ren, X. J. (2017). The employment and countermeasures solutions of college graduates. 3rd International Conference on Education and Social Development, 889-891.

Rok, M., \& Lebe, S. S. (2016). Enhancing graduate employability. Academia Turistica, 9(1), 73-83.

Sin, C., Neave, G. (2016). Employability deconstructed: Perceptions of Bologna stakeholders. Studies in higher education, 41(8), 1447-1462. https://doi.org/10.1080/03075079.2014.977859

Saleh, N. S., \& Rosli, M. S. (2019). Kepentingan pembelajaran abad ke 21 terhadap potensi kebolehpasaran modal insan. Innovative Teaching and Learning Journal, 2(2), 71-81.

Schmidt, V. A. (2015). Institutionalism. In the Encyclopaedia of political thought. First Edition. Gibbons, M. T. (2015). John Wiley \& Sons, Ltd.

St Jorre, T. J., \& Oliver, B. (2017). Want student to engage? Contextualise graduate learning outcomes and assess for employability. Higher Education Research \& Development, $1-15$.

Sukadi, W. M. W., Atan, N. A., \& Abdul-Rahim, R. (2015). Program sangkutan industri pensyarah di kalangan pegawai Pendidikan Pengajian Tinggi (PPPT) Jabatan Pelancongan dan Hospitaliti. Tourisim and Hospitality Essentials (THE) Journal, 2, 955966.

Sun, S. (2019). Research on the reform of employment-oriented curriculum in Higher Education. Advances in Economics, Business and Management Research, 7, 255-258.

Tan, A. Y., Chew, E., \& Kalavally, V. (2017). The expectations gap for engineering field in Malaysia in the 21st century. On the Horizon, 25(2), 131-138. 
Tanius, E. (2018). Employability skills-A study on the perception of business students graduates and employers in Malaysia. Asia Pacific Journal of Research in Business Management, 9(1), 86-99.

Velasco, M. S. (2014). Do higher education institutions make a difference in competence development? A model of competence production at university. Higher Education, $1-21$.

Vona, F., \& Consoli, D. (2014). Innovation and skill dynamics: A life-cycle approach. Industrial and Corporate Change, 1-23.

Wahyuni, D. (2012). The research design maze: Understanding paradigms, cases, methods and methodologies. Journal of Applied Management Accounting Research, 10(1), 69-80.

Wickramasinghe, V., \& Perera, L. (2010). Graduates', university lecturers' and employers' perceptions towards employability skills. Education \& Training, 52(3), 226 - 244.

Yusoff, I., Ismail, R., \& Sidin, R. (2008). Graduan dan alam pekerjaan: Kes siswazah UKM. Journal Academia, 72, 3-24.

Yusof, N., \& Jamaluddin, Z. (2017). Pembangunan kebolehpasaran siswazah: Tindakan universiti dan cabaran yang dihadapi. Jurnal Personalia Pelajar, 20, 15-32.

Yusof, N., Jamaluddin, Z., \& Mat-Lazim, N. (2013). Persepsi pelajar prasiswazah terhadap kebolehpasaran graduan dan persaingan dalam pasaran pekerjaan. Journal Personalia Pelajar, 16, 7792.

Yusof, N., Kaur, A., Sani, M. A., \& Hashim, R. A. (2019). A qualitative expert interview approach towards understanding religious extremism among Malaysian youth. The Qualitative Report, 24(7), 1577-1592. Retrieved from https://nsuworks. nova.edu/tqr/vol24/iss $7 / 5$ 